Bull. Chem. Soc. Ethiop. 2020, 34(1), 13-23.

ISSN 1011-3924

(c) 2020 Chemical Society of Ethiopia and The Authors

Printed in Ethiopia

DOI: https://dx.doi.org/10.4314/bcse.v34i1.2

\title{
DIRECT DETERMINATION OF PIROXICAM IN PHARMACEUTICAL FORMS USING FLOW INJECTION-SPECTROPHOTOMETRY
}

\author{
Ream Ismail Abed and Hind Hadi* \\ Department of Chemistry, College of Science, University of Baghdad, Baghdad, Iraq
}

(Received August 16, 2019; Revised February 6, 2020; Accepted February 16, 2020)

\begin{abstract}
In this research, direct batch and flow injection (FI) spectrophotometric methods for the analysis of piroxicam (PIX) in commercial dosage forms were investigated. The methods were based on the reaction of PIX with diazotized metoclopramide in alkaline medium to form orange color product at room temperature which absorbs maximally at $\lambda_{\max } 472 \mathrm{~nm}$. Chemical and physical variables of batch and FI methods were optimized to produce high sensitivity and reproducibility. Under the optimized experimental conditions, Beer's law was obeyed over concentration ranges from $1-35$ and $10-250 \mu \mathrm{g} / \mathrm{mL}$ PIX with limits of detection of 0.2 and $3.4 \mu \mathrm{g} / \mathrm{mL}$ and limits of quantification of 0.7 and $11.4 \mu \mathrm{g} / \mathrm{mL}$ PIX for batch and FI procedures, respectively. The relative standard deviation (\%RSD) was less than 0.7 and 2.4 for batch and FI procedures respectively with a sample throughput of $38 \mathrm{~h}^{-1}$ for FI procedure. The proposed methods can be used for the routine analysis for the assay of PIX in injections and capsules.
\end{abstract}

KEY WORDS: Piroxicam, Metoclopramide, Diazotization reaction, Flow injection

\section{INTRODUCTION}

Piroxicam (PIX) $\left(\mathrm{C}_{15} \mathrm{H}_{13} \mathrm{~N}_{3} \mathrm{O}_{4} \mathrm{~S}\right)$ is chemically known as 4-hydroxy-2-methyl-3-(N-pyridil-2)carboxyamido-2H-,2-benzothiazine-1,1-dioxide. It is a non-steroidal anti-inflammatory agent that is widely used in the treatment of inflammatory conditions such as rheumatic fever, rheumatoid arthritis, non-specific polyarthritis, and osteoarthritis [1]. Therapeutic dose of PIX is $20 \mathrm{mg}$ daily, but it can cause several gastrointestinal upset symptoms at high dose [2], therefore, the assay of PIX is recommended to gain the optimal therapeutic level and to ensure good quality assurance in pharmaceutical products. PIX has been determined by several reported methods included high performance liquid chromatography (HPLC) [3, 4], extraction by magnetic imprinted polymeric nanosorbent [5], ultrasonic assisted magnetic dispersive solid phase microextraction [6], capillary electrophoresis (CE) [7, 8], and voltammetry [9]. The literature reported several spectrophotometric methods [10-20] and a few flow injection methods [21-24] for the determination of PIX in dosage forms. Most of these methods involved redox reactions [10-13], or formation of ion association complexes with basic dyes [14, 15]. However, most of these methods are indirect $[11,18,19]$ or suffer from disadvantages such as dependence on temperature, poor reproducibility, instability of the colored product, time consuming and unsuitable for routine analysis of the drug. As a result, the development of the direct, rapid and inexpensive method for the assay of PIX in pharmaceutical forms is essential. Flow-injection analysis (FIA) is considered as speed and inexpensive technique used in routine analysis. It is very useful for the automated reactions which do not reach equilibrium or those not sufficiently stable over time [25, 26]. The present work describes the development of direct batch and FIA methods for the determination of PIX using another drug (metoclopramide (MP)) as a green and safe reagent. The diazotization coupling reaction between PIX and diazotized metoclopramide (DMP) in the presence of sodium hydroxide as an alkaline medium produced orange product measured spectrophotometrically at $472 \mathrm{~nm}$. The methods are applied for the assay of PIX in pure and dosage forms.

*Corresponding author. E-mail: Hindhadi13@yahoo.com

This work is licensed under the Creative Commons Attribution 4.0 International License 


\section{EXPERIMENTAL}

\section{Apparatus}

The absorbance measurements were performed using a Shimadzu UV-Visible 1240 digital single beam recording spectrophotometer. Flow injection equipment involved a flow cell $(50 \mu \mathrm{L}$ and $1 \mathrm{~cm}$ path length), a peristaltic pump (Ismatec, Labortechnik-Analytik, CH-8152, Switzerland) used for pumping the solutions. Also, an injection valve (Rheodyne, Altex 210, Supelco-USA) used for injection microliter volumes of samples. Solutions of reagents were pumped through a flexible vinyl tubing $(0.5 \mathrm{~mm}$ i.d.), while the reaction coil (RC) was made from Teflon tubes $(0.5 \mathrm{~mm}$ i.d.). A double-channel manifold (Figure 1) was adopted for applying the FI procedure. The first channel was used for transport DMP, while the other one used for transport $\mathrm{NaOH}$ solution. Through the injection valve, PIX solution was injected into the stream of the DMP and then mixed with the base in RC. The peristaltic pump (total flow rate of $1.47 \mathrm{~mL} / \mathrm{min}$ was used for propelled the solution during the manifold. The absorbance of the product was measured at the end of the manifold at $\lambda_{\max } 472 \mathrm{~nm}$.

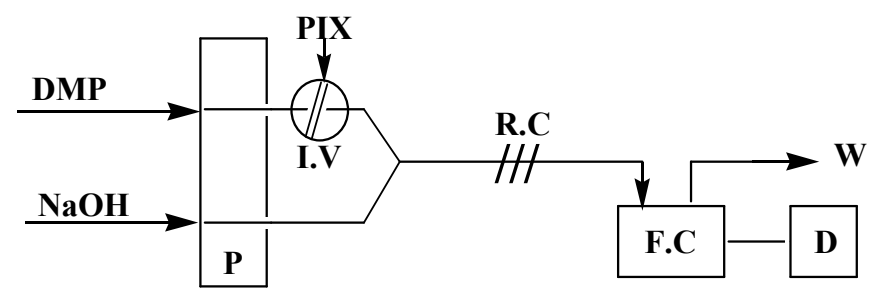

Figure 1. FIA manifold (I.V, injection valve; PIX, piroxicam; P, peristaltic pump; R.C, reaction coil; F.C, flow cell; W, waste; D, detector).

Reagents

All reagents used were of analytical reagent grade. The standard materials of PIX and MP (99.9\% pure) also the excipients were kindly donated by the Iraqi Pharmaceutical Manufacturing Company (SDI-Samarra/Iraq). HPLC grade ethanol was obtained from SigmaAldrich (USA). Pharmaceutical forms of PIX (Piroxicam ${ }^{\circledR}$ capsules $20 \mathrm{mg}$ /Micro Labs limited/Indian-SOTILEN $10 \mathrm{mg}$ capsules/Cyprus-Feldene injection-Piroxicam $20 \mathrm{mg} / 1 \mathrm{~mL}-$ Pfizer/USA) were purchased from the local market. Sodium hydroxide and sodium nitrite were supplied from Merck (Germany). $\mathrm{HCl}(36 \% \mathrm{w} / \mathrm{w})$ was an analytical-reagent grade and purchased from Sigma-Aldrich (USA).

Preparation of standard and reagents solutions

Piroxicam standard solution $(250 \mu \mathrm{g} / \mathrm{mL})$. A $0.0250 \mathrm{~g}$ of PIX was dissolved in $25 \mathrm{~mL}$ ethanol in a $100 \mathrm{~mL}$ volumetric flask and then the solution was completed to the mark with distilled water. The working standard solution was prepared by simple diluting with distilled water.

Diazotized metoclopramide hydrochloride $(5 \mathrm{mM})$. This solution was prepared daily by weighing a $0.1772 \mathrm{~g}$ of MP and dissolved in a minimum volume of distilled water in a $100 \mathrm{~mL}$ volumetric flask then $3 \mathrm{~mL}$ of $1 \mathrm{M} \mathrm{HCl}$ was added while keeping the temperature of the solution at $0-5{ }^{\circ} \mathrm{C}$ for $5 \mathrm{~min}$ in ice-bath. A weight of $0.0345 \mathrm{~g}$ amount of $\mathrm{NaNO}_{2}$ was added with shaking for $5 \mathrm{~min}$ and then completed the volume to the mark with distilled water. 
Sodium hydroxide solution $(0.1 \mathrm{M})$. A $1 \mathrm{~g}$ of the $\mathrm{NaOH}$ was dissolved in $250 \mathrm{~mL}$ distilled water and then standardized.

Hydrochloric acid solution $(1 \mathrm{M})$. Prepared diluted acid solution was made by appropriate dilution of $85.84 \mathrm{~mL}$ of concentrated solution $(11.65 \mathrm{M})$ with $1 \mathrm{~L}$ distilled water in a volumetric flask.

Analysis of PIX in capsules and injections

Weighed and mixed the contents of 10 capsules or mixed content of 5 vials (commercially available). An accurately weighed amount of the powder (equivalent to $25 \mathrm{mg}$ of the pure drug contents), were taken and dissolved in $25 \mathrm{~mL}$ ethanol and completed the $100 \mathrm{~mL}$ calibrated flask to the mark with distilled water into. The flasks were shaken well for $15 \mathrm{~min}$ then filtered. The amount of PIX was determined as recommended under the general procedure.

\section{Batch procedure}

A series of volumes of standard PIX solution, covering the concentration range of $1-35 \mu \mathrm{g} / \mathrm{mL}$, were transferred into a series of $10 \mathrm{~mL}$ standard volumetric flasks. To each flask, $1.0 \mathrm{~mL}$ of DMP $(5 \mathrm{mM})$ and $1.5 \mathrm{~mL}$ of $\mathrm{NaOH}(0.1 \mathrm{M})$ solution were transferred then diluted with distilled water and mixed well. The reaction reaches to maximum intensity and stability after $5 \mathrm{~min}$, then the absorbance was measured at $472 \mathrm{~nm}\left(\right.$ at $\left.25{ }^{\circ} \mathrm{C}\right)$ against reagent blank. The amount of the PIX was obtained from the regression equation of the calibration graph. In all batch optimization experiments a $12.5 \mu \mathrm{g} / \mathrm{mL}$ of PIX was used.

\section{FIA procedure}

A $100 \mu \mathrm{L}$ of PIX standard solution (range of $10-250 \mu \mathrm{g} / \mathrm{mL}$ ) was injected through the injection valve utilizing a syringe. Samples of PIX were injected into the stream of the $5 \mathrm{mM}$ of DMP. The resultant solution was mixed with $0.1 \mathrm{M} \mathrm{NaOH}$ solution in the reaction coil. Peristaltic pump pumped the solutions with a total flow rate of $1.47 \mathrm{~mL} / \mathrm{min}$ and the absorbance of the resulting orange product was measured at $472 \mathrm{~nm}$. A $40 \mu \mathrm{g} / \mathrm{mL}$ of PIX was used during the study of the optimum conditions of FI system.

\section{RESULTS AND DISCUSSION}

Diazotized metoclopramide has been used as an efficient coupling reagent in several spectrophotometric reactions [27, 28]. Most of the amino compounds used for diazotization coupling reactions are toxic, especially those contain withdrawing groups (nitro, cyano and halo groups). Using a drug compound as a chromogenic reagent is preferred to make the methods less expensive and safer. In the present work, an orange dye product results from the coupling of PIX with DMP was studied using batch and normal FIA methods. All the parameters that enhance the sensitivity of the diazotization reaction and consequently the assay of PIX drug were studied. The influence of the chemical and physical parameters such as reagents concentrations, the temperature of the reaction, the flow rate, length of reaction coil and sample volume were optimized.

\section{Preliminary studies and batch system}

The maximum value of absorption was measured at $472 \mathrm{~nm}$ versus reagent blank (Figure 2). The alkaline medium was found to be essential for development of the colored product because 
the benzothiazine ring in PIX be more reactive due to conversion of the hydroxyl group to more reactive phenoxide in the presence of sodium hydroxide. Therefore, different alkaline solutions (sodium hydroxide, ammonium hydroxide, and sodium carbonate) were examined. Maximum sensitivity was obtained when sodium hydroxide solution was used.

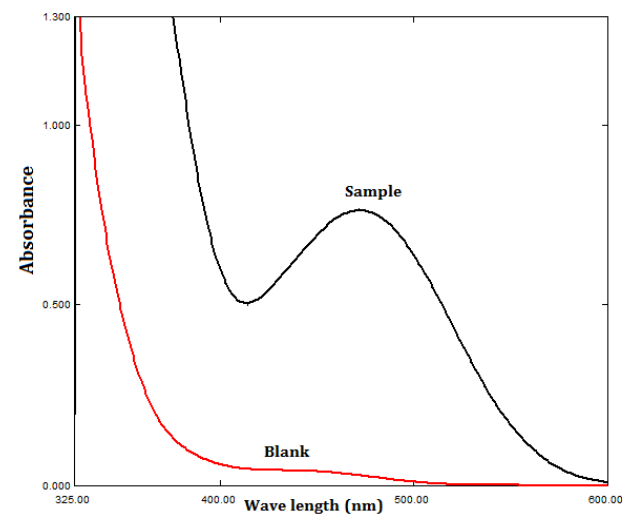

Figure 2. Absorption spectra of the orange product result from the reaction of $20 \mu \mathrm{g} / \mathrm{mL}$ of PIX with $\mathrm{DMP} / \mathrm{NaOH}$ measured against the blank, and the blank measured against distilled water.

When the influence of different volumes of $5 \mathrm{mM}$ of DMP (from 0.25 to $3 \mathrm{~mL}$ ) and $0.1 \mathrm{M}$ $\mathrm{NaOH}$ (from 0.1 to $2.5 \mathrm{~mL}$ ) were studied, maximum absorbances were obtained using $1 \mathrm{~mL}$ of 5 $\mathrm{mM}$ DMP and $1.5 \mathrm{~mL}$ of $0.1 \mathrm{M}$ sodium hydroxide (Figure 3 ). The effect of time on the stability of absorbance readings after dilution was studied. The absorbance of the product was stable after $5 \mathrm{~min}$ and remain constant for more than $20 \mathrm{~min}$. Also, variant orders of the addition of the reagents were examined and it was found that the following order addition (PIX+DMP $+\mathrm{NaOH})$ was effective to obtain the aimed results and therefore used in all the following experiments.

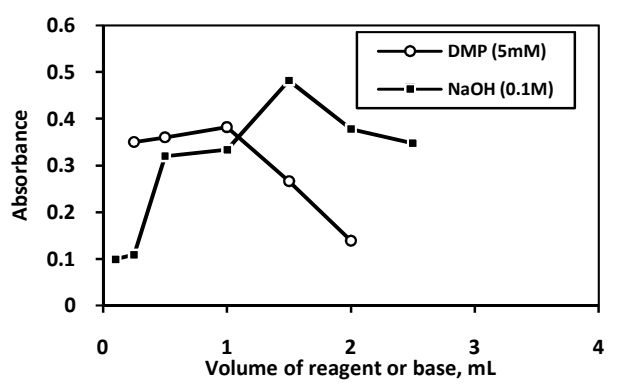

Figure 3. Effect of the volume of DMP and $\mathrm{NaOH}$.

Scheme 1 is summarized as the supposed mechanism of the reaction. The reagent used in this work is an amino drug (MP), which is easily converted to diazonium salt under diazotization reaction with nitrous acid $\left(\mathrm{NaNO}_{2} / \mathrm{HCl}\right)$. The diazonium salt then is reacted with PIX through the benzothiazine ring (i.e. from benzene ring attached to the 6-membered heterocycle thiazine) in alkaline medium. The stoichiometry of the PIX-DMP dye was studied by applying Job's and molar ratio methods using equimolar concentrations $\left(1 \times 10^{-3} \mathrm{M}\right)$ of the 
Determination of piroxicam in pharmaceutical forms using flow injection-spectrophotometry 17

drug and DMP under the recommended optimum conditions. A stoichiometry of 1:1 PIX:DMP was found with $\varepsilon$ (molar absorbtivity) value of $1.15 \times 10^{4} \mathrm{~L} / \mathrm{mol} \mathrm{cm}$.

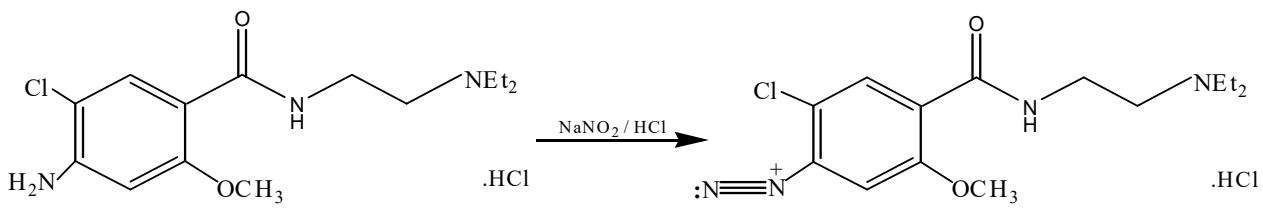

Metochlopramide(MP)

Diazotized metochlopramide(DMP)

$$
(\mathrm{R}-\stackrel{\mathrm{N}}{=} \mathrm{N}:)
$$<smiles>[R][N+]=[N+]=[N-]</smiles>

$\mathrm{NaOH}$<smiles>[R]NN=C1C=CC=C2C1C(O)=C(C(=O)Nc1ccccn1)N(C)S2(=O)=O</smiles><smiles>C1CCC2(CC1)CCCC2</smiles><smiles>[R]c1cc(OC)c(C(=O)NCCNCCCC)cc1Cl</smiles>

Scheme 1. Proposed reaction mechanism.

\section{FIA system}

Primary studies were focused on the optimization of all parameters of FIA system. The manifold is considered as a heart of flow system, therefore several flow manifolds (single and double channels) were made to perform different reaction paths for the reaction of PIX drug with DMP in alkaline medium. A two-channel FI manifold was chosen, which offered a maximum absorbance intensity and high sampling frequency. PIX was injected into a stream of DMP, which then mixed with sodium hydroxide using mixing coil as given in Figure 1. 
Optimization of chemical variables

The effect of the concentration of DMP on the analytical signal was studied. A $40 \mu \mathrm{L}$ of PIX was injected into a stream of different concentrations range of DMP $(2-10 \mathrm{mM})$. The results (Figure 4A) indicated that a $5 \mathrm{mM}$ gave the best analytical signal and was selected for further use. Previous studies indicated that the reaction between PIX and DMP must be performed in an alkaline medium. The effect of changing the concentration of $\mathrm{NaOH}$ using a range of concentration $(0.025-0.3 \mathrm{M})$ was studied. The best result was obtained using $0.1 \mathrm{M}$ sodium hydroxide (Figure 4A) which was selected for the following experiments.

Optimization of FIA variables

The influence of the total flow rate of the reagents streams on the sensitivity and sample frequency of the reaction was studied using a range of rates between $1.13-4.80 \mathrm{~mL} / \mathrm{min}$ under the optimum conditions. Figure 4B referred that maximum intensity was obtained with a flow rate of $1.47 \mathrm{~mL} / \mathrm{min}$, then the absorbance was decreased with increasing the flow rate because of increasing the dispersion which decreased residence time and increased reagent consumption. The effect of length of the coil (using mixed the solutions) on absorbance was examined in the range of $0-200 \mathrm{~cm}$. A significant increase in absorbance (peak height) was observed after increasing the coil length up to $75 \mathrm{~cm}$ and then decreased (Figure 4C). This may be due to the fast coupling reaction between PIX and DMP. Further length of reaction coil causes an increase in the dispersion, and peak broadening, hence $75 \mathrm{~cm}$ was selected for the subsequent experiments.

The injected sample volume was studied by changing the length of $0.5 \mathrm{~mm}$ i.d. sample loop in the injection valve to obtain varied volumes from 75 to $200 \mu \mathrm{L}$, whereas the other parameters remained unchanged $(75 \mathrm{~cm}$ coil length, $1.47 \mathrm{~mL} / \mathrm{min}$ flow rate, $0.1 \mathrm{M} \mathrm{NaOH}, 5 \mathrm{mM}$ DMP solution and $40 \mu \mathrm{g} / \mathrm{mL}$ of PIX). The results (Figure 4D) showed an increase in analytical signal with an increase in the injected volume up to $100 \mu \mathrm{L}$ and then decreased. A $100 \mu \mathrm{L}$ was selected to obtained high intensity and low consumption of the sample. The flow system provided a sampling frequency of 38 samples $\mathrm{h}^{-1}$.

\section{Calibration plots and limits of detection}

The calibration graphs for the analysis of PIX drug using batch and FIA systems were obtained using the optimum variables. The calibration graphs were prepared using a series of PIX standard solutions and by applying the procedure described in experimental or by injected in triplicate to test the linearity for batch and FIA systems, respectively. The slope, correlation coefficient, intercept for the calibration data and the sensitivity parameters (molar absorptivity, Sandell's sensitivity, and LOD) are summarized in Table 1. Excellent linearity of the calibration graphs was obtained and Beer's law was obeyed in the range of 1-35 and 10-250 $\mu \mathrm{g} / \mathrm{mL}$ of PIX for batch and FIA systems, respectively. In comparison between two suggested procedures, FIA is more convenient than the batch method because of its wider linear range of calibration graph and high throughput samples ( 38 sample/h). The FIA method is less sensitive than the batch method, this may be due to the effect of dispersion of the sample zone inside the carrier and reagent solutions arriving at the detector.

\section{Accuracy and precision}

The precision of the methods was tested by analyzing three different concentrations of PIX solutions according to suggested methods in five replicates. The resulting analytical values have been shown in Table 2. The method displayed good accuracy and high precision according to the small values of RSD and \% Error [29]. 
Determination of piroxicam in pharmaceutical forms using flow injection-spectrophotometry 19
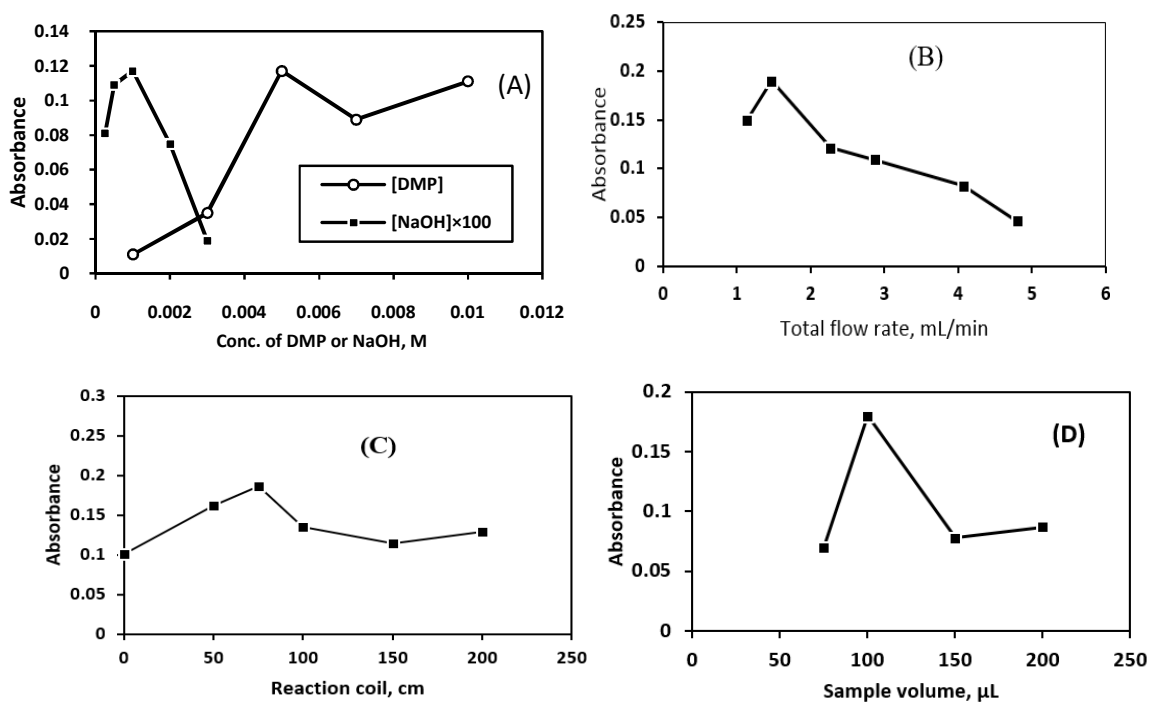

Figure 4. Effect of reagent concentrations (A); total flow rate (B); reaction coil (C); and sample volume (D).

Table 1. Data for the calibration graphs for batch and FIA methods.

\begin{tabular}{|l|l|l|}
\hline Parameter & Batch method & FIA method \\
\hline Regression equation & $\mathrm{Y}=0.0346 \mathrm{X}-0.0204$ & $\mathrm{Y}=0.0012 \mathrm{X}+0.1218$ \\
\hline Linear range $(\mu \mathrm{g} / \mathrm{mL})$ & $1-35$ & $10-250$ \\
\hline Correlation coefficient, $\mathrm{r}$ & 0.9998 & 0.9997 \\
\hline Molar absorptivity, $\varepsilon(\mathrm{L} / \mathrm{mol} \mathrm{cm})$ & $1.2 \times 10^{4}$ & $0.4 \times 10^{3}$ \\
\hline Sandell's sensitivity, $\mathrm{S}\left(\mu \mathrm{g} / \mathrm{cm}^{2}\right)$ & $2.9 \times 10^{-2}$ & $8.3 \times 10^{-1}$ \\
\hline Limit of detection $(\mathrm{s} / \mathrm{n}=3)(\mu \mathrm{g} / \mathrm{mL})$ & 0.2 & 3.4 \\
\hline Limit of quantification $(\mu \mathrm{g} / \mathrm{mL})$ & 0.7 & 11.4 \\
\hline Reproducibility, $\%$ & $<0.7$ & $<2.4$ \\
\hline Through-put $\left(\mathrm{h}^{-1}\right)$ & 12 & 38 \\
\hline Average of recovery, $\%$ & 99.0 & 100.3 \\
\hline Slope, $\mathrm{b}(\mathrm{mL} / \mu \mathrm{g})$ & 0.0346 & 0.0012 \\
\hline Intercept, a & -0.0204 & 0.1218 \\
\hline $\mathrm{S}_{\mathrm{y} / \mathrm{x}}$ & $9.8 \times 10^{-3}$ & $2.8 \times 10^{-3}$ \\
\hline $\mathrm{S}_{\mathrm{b}}$ & $3.1 \times 10^{-4}$ & $1.1 \times 10^{-5}$ \\
\hline $\mathrm{S}_{\mathrm{a}}$ & $5.2 \times 10^{-3}$ & $1.6 \times 10^{-3}$ \\
\hline & & \\
\hline
\end{tabular}

Table 2. Accuracy and precision of the proposed methods.

\begin{tabular}{|c|c|c|c|c|c|c|c|c|}
\hline Sample & \multicolumn{9}{|c|}{ Proposed methods } \\
\cline { 2 - 9 } & $\begin{array}{c}\text { Added } \\
\text { conc. } \\
(\mu \mathrm{g} / \mathrm{mL})\end{array}$ & $\begin{array}{c}\text { Found } \\
\text { conc. } \\
(\mu \mathrm{g} / \mathrm{mL})\end{array}$ & $\begin{array}{c}\text { RE } \\
(\%)\end{array}$ & $\begin{array}{c}(\text { Rec. } \pm \text { SD }) \% \\
(\mathrm{n}=5)\end{array}$ & $\begin{array}{c}\text { Added } \\
\text { conc. } \\
(\mu \mathrm{g} / \mathrm{mL})\end{array}$ & $\begin{array}{c}\text { Found } \\
\text { conc. } \\
(\mu \mathrm{g} / \mathrm{mL})\end{array}$ & $\begin{array}{c}\text { RE } \\
(\%)\end{array}$ & $\begin{array}{c}(\text { Rec. } \pm \text { SD }) \% \\
(\mathrm{n}=5)\end{array}$ \\
\hline 1 & 5 & 4.8 & -4.0 & $96 \pm 0.1$ & 25 & 24.9 & -0.4 & $99.6 \pm 0.2$ \\
\hline 2 & 10 & 10.3 & 3.0 & $103 \pm 0.2$ & 75 & 75.6 & 0.8 & $100.8 \pm 0.5$ \\
\hline 3 & 20 & 19.8 & -1.0 & $99 \pm 0.2$ & 100 & 100.2 & 0.2 & $100.2 \pm 0.3$ \\
\hline
\end{tabular}

Bull. Chem. Soc. Ethiop. 2020, 34(1) 
Study of interference from other substances

To check the efficacy of the proposed methods in the assay of PIX in commercial dosage forms (usually involved an additives materials), a recovery testing for $10 \mu \mathrm{g} / \mathrm{mL}$ of PIX was performed in the presence of (10-fold) of additives for batch method. The good percentage recoveries (97.19-102.16\%) were obtained indicating none of these additives interfered significantly and the method has good selectivity (Table 3).

Table 3. Analysis of PIX in the presence of common interferences.

\begin{tabular}{|l|c|c|c|}
\hline \multirow{2}{*}{$\begin{array}{l}\text { Additives } \\
(100 \mu \mathrm{g} / \mathrm{mL})\end{array}$} & \multicolumn{2}{|c|}{ Conc. of PIX, $\mu \mathrm{g} / \mathrm{mL}$} & \multirow{2}{*}{${\text { (\% Recovery } \pm \mathrm{SD})^{*}}^{*}$} \\
\cline { 3 - 4 } & Present & Found & \\
\hline \multirow{3}{*}{ Poly vinyl pyrrolidone } & \multirow{3}{*}{10} & 10.2 & $102 \pm 0.5$ \\
\cline { 1 - 1 } Talc & & 10.1 & $101 \pm 1.8$ \\
\cline { 1 - 1 } Starch & 9.7 & $97 \pm 0.8$ \\
\cline { 3 - 4 } Magnesium stearate & & 9.7 & $97 \pm 0.4$ \\
\cline { 3 - 4 } & & & \\
\hline
\end{tabular}

Average of four determinations.

\section{Ruggedness}

The ruggedness of the suggested methods was established by assaying PIX by different analysts using the same conditions at 12.5 and $40 \mu \mathrm{g} / \mathrm{mL}$ of PIX for the batch and FIA methods, respectively. The results showed that the $\%$ RSD values were less than $2 \%$ and $1.5 \%$ for batch and FIA methods, respectively, indicated the ruggedness of both methods.

Table 4. Application of the batch, FIA and reference methods to the determination of PIX in different dosage forms.

\begin{tabular}{|c|c|c|c|c|c|c|c|c|c|c|c|c|}
\hline \multirow{4}{*}{ Dosage form } & \multicolumn{8}{|c|}{ Proposed methods } & \multicolumn{4}{|c|}{ UV method } \\
\hline & \multicolumn{4}{|c|}{ Batch } & \multicolumn{4}{|c|}{ FIA } & & & & \\
\hline & \multicolumn{2}{|c|}{ Conc. $(\mu \mathrm{g} / \mathrm{mL})$} & \multirow{2}{*}{$\begin{array}{l}\text { Rec. } \\
(\%)^{*}\end{array}$} & \multirow{2}{*}{$\begin{array}{l}\text { RSD } \\
(\%)^{*}\end{array}$} & \multicolumn{2}{|c|}{ Conc. $(\mu \mathrm{g} / \mathrm{mL})$} & \multirow{2}{*}{$\begin{array}{l}\text { Rec. } \\
(\%)^{*}\end{array}$} & \multirow{2}{*}{$\begin{array}{l}\text { RSD } \\
(\%)^{*}\end{array}$} & \multicolumn{2}{|c|}{ Conc. $(\mu \mathrm{g} / \mathrm{mL})$} & \multirow{2}{*}{$\begin{array}{l}\text { Rec. } \\
(\%)^{*}\end{array}$} & \multirow{2}{*}{$\begin{array}{l}\text { RSD } \\
(\%)^{*}\end{array}$} \\
\hline & Taken & Found & & & \begin{tabular}{|l} 
Taken \\
\end{tabular} & Found & & & \begin{tabular}{|l|} 
Taken \\
\end{tabular} & Found & & \\
\hline \multirow{3}{*}{$\begin{array}{l}\text { Piroxicam }{ }^{\circledR} \\
\text { capsules } \\
(20 \mathrm{mg})\end{array}$} & 5 & 5.1 & 102.0 & 4.3 & 75 & 76.9 & 102.5 & 1.4 & 5 & 4.8 & \begin{tabular}{|l|}
96.0 \\
\end{tabular} & 2.2 \\
\hline & 10 & 9.8 & 98.0 & 0.9 & 100 & 98.7 & $\begin{array}{l}98.7 \\
\end{array}$ & 1.8 & 15 & 14.9 & \begin{tabular}{|l|}
99.3 \\
\end{tabular} & 0.6 \\
\hline & 15 & 14.9 & 99.3 & 0.5 & 150 & 145.9 & 97.3 & 1.1 & & & & \\
\hline \multirow{3}{*}{$\begin{array}{l}\text { SOTILEN } \\
\text { capsules } \\
(10 \mathrm{mg})\end{array}$} & 5 & 4.9 & 98.0 & 2.2 & 75 & 73.9 & 98.5 & 1.9 & 5 & 5.1 & $\mid 102.0$ & 2.9 \\
\hline & 10 & 10.1 & 101.0 & 1.2 & 100 & 101.7 & 101.7 & 1.5 & 15 & 15.0 & 100.0 & 0.7 \\
\hline & 15 & 14.9 & 99.3 & 0.6 & 150 & 145.3 & 96.9 & 2.2 & & & & \\
\hline \multirow{3}{*}{$\begin{array}{l}\text { Feldene } \\
\text { Piroxicam }{ }^{\circledR} \\
\text { injection } \\
(20 \mathrm{mg} / 1 \mathrm{~mL}) \\
\end{array}$} & 5 & 5.1 & 102.0 & 2.3 & 75 & 76.1 & 101.5 & 1.8 & 5 & 5.1 & $\mid 102.0$ & 1.3 \\
\hline & 10 & 10.2 & 102.0 & 1.1 & 100 & 97.3 & 97.3 & 1.6 & 15 & 14.8 & 98.7 & 0.8 \\
\hline & 15 & 15.2 & 101.3 & 2.6 & 150 & 154.1 & 102.7 & 1.1 & & & & \\
\hline PIX (pure form) & & & 99.0 & & & & 100.3 & & & & \begin{tabular}{|l|}
99.3 \\
\end{tabular} & \\
\hline $\begin{array}{l}\mathrm{t}(2.45)^{* *} \\
\mathrm{~F}(9.28)^{* *}\end{array}$ & \multicolumn{4}{|l|}{$\begin{array}{c}0.31 \\
1.34\end{array}$} & \multicolumn{4}{|l|}{\begin{tabular}{|l|}
0.14 \\
4.68
\end{tabular}} & \multicolumn{4}{|c|}{$\begin{array}{l}(\mathrm{n} 1-1)=3,(\mathrm{n} 2-1)=3 \\
(\mathrm{n} 1+\mathrm{n} 2-2)=6\end{array}$} \\
\hline
\end{tabular}

*For five determinations. Conc., concentration; $* *$ Theoretical value. 
Determination of piroxicam in pharmaceutical forms using flow injection-spectrophotometry 21

Table 5.Comparison between suggested methods and some literature spectrophotometric methods.

\begin{tabular}{|c|c|c|c|c|c|c|}
\hline FIA methods & Reagent & $\begin{array}{l}\text { Linearity } \\
\text { range } \\
(\mu \mathrm{g} / \mathrm{mL})\end{array}$ & $\begin{array}{l}\text { LOD } \\
(\mu \mathrm{g} / \mathrm{mL})\end{array}$ & $\begin{array}{l}\text { RSD } \\
\%\end{array}$ & Remarks & Ref. \\
\hline Spectrophotometry & $\begin{array}{l}\text { Ceric ammonium sulfate/ } \\
\text { promethazine } \mathrm{HCl} \\
\text { Ceric ammonium sulfate/ } \\
\text { methdilazine } \mathrm{HCl}\end{array}$ & $\begin{array}{l}0.4-7.5 \\
0.2-10\end{array}$ & $\mid---$ & $\begin{array}{l}0.8 \\
0.9\end{array}$ & Indirect methods & 11 \\
\hline Spectrophotometry & Potassium iodate $/ \mathrm{H}_{2} \mathrm{SO}_{4}$ & $0.05-1.1$ & ---- & 0.6 & $\begin{array}{l}\text { Involved extraction } \\
\text { with cyclohexane }\end{array}$ & 13 \\
\hline Spectrophotometry & Methylene Violet & $2-25$ & --- & 1.2 & $\begin{array}{l}\text { Involved extraction } \\
\text { with chloroform and } \\
\text { need pH control }\end{array}$ & 14 \\
\hline Spectrophotometry & $\begin{array}{l}\text { Alizarin, alizarin red } \mathrm{S}, \\
\text { alizarin yellow } \mathrm{G} \text { and } \\
\text { quinalizarin }\end{array}$ & $0.05-2.40$ & $0.012-0.014$ & $\begin{array}{l}0.08- \\
1.2\end{array}$ & $\begin{array}{l}\text { Using organic solvent } \\
\text { and need } \mathrm{pH} \text { control }\end{array}$ & 16 \\
\hline Spectrophotometry & $\mathrm{Fe}(\mathrm{III})$ & $8-160$ & 0.78 & 0.1 & Low sensitivity & 17 \\
\hline Spectrophotometry & Polymethine dye & $1.0-20.0$ & 0.49 & $\begin{array}{l}0.06- \\
0.1\end{array}$ & $\begin{array}{l}\text { Need } \mathrm{pH} \text { control, } \\
\text { extraction with toluene } \\
\text { and expensive reagent }\end{array}$ & 19 \\
\hline $\begin{array}{l}\text { FIA- } \\
\text { Spectrophotometry }\end{array}$ & $\begin{array}{l}\text { N-bromosuccinimide } \\
\text { (NBS)/chloranilic acid }\end{array}$ & $10-160$ & 6 & 1.7 & Indirect method & 21 \\
\hline FIA- Luminescence & Europium $\left(\mathrm{Eu}^{3+}\right)$ & $0.1-1$ & 0.023 & $2-3$ & $\begin{array}{l}\text { Toxic and expensive } \\
\text { reagent, narrow range } \\
\text { of linearity }\end{array}$ & 22 \\
\hline $\begin{array}{l}\text { FIA- } \\
\text { Spectrophotometry }\end{array}$ & $\begin{array}{l}\mathrm{HCl} / \mathrm{CH}_{3} \mathrm{OH} \\
\mathrm{Fe}(\mathrm{III}) / \mathrm{CH}_{3} \mathrm{OH}\end{array}$ & $\begin{array}{l}0.5-15 \\
30-500 \\
\end{array}$ & \begin{tabular}{|l|}
0.15 \\
7.5 \\
\end{tabular} & $\begin{array}{l}0.2- \\
0.3 \\
\end{array}$ & $\begin{array}{l}\text { Using organic solvent } \\
\text { and less sensitive }\end{array}$ & 23 \\
\hline $\begin{array}{l}\text { FIA- } \\
\text { Chemiluminescence }\end{array}$ & $\begin{array}{l}\text { Tris (2,2-bipyridyl) } \\
\text { Ruthenium(II)/ } \mathrm{KMnO}_{4} / \\
\mathrm{H}_{2} \mathrm{SO}_{4}\end{array}$ & $0.009-9.94$ & 0.003 & 1.5 & $\begin{array}{l}\text { Toxic and expensive } \\
\text { reagent }\end{array}$ & 24 \\
\hline Spectrophotometry & $\begin{array}{l}\text { Diazotized } \\
\text { metoclopramide }\end{array}$ & $1-35$ & 0.2 & 0.7 & $\begin{array}{l}\text { Sensitive not involved } \\
\text { extraction or heating. } \\
\text { Using safe and cheap } \\
\text { drug compound as } \\
\text { reagent }\end{array}$ & $\begin{array}{l}\text { This } \\
\text { work }\end{array}$ \\
\hline
\end{tabular}

\section{Analysis of pharmaceutical samples}

The batch and FIA methods were successfully used for the analysis of pharmaceuticals (capsules and injection) involved different dosages of PIX and the results are summarized in Table 4. The evaluation of the proposed methods was performed by carrying out recovery experiments for two types of capsules and one type of injection and the results showed excellent recoveries values for both methods and were in good agreement with the declared content. The obtained recoveries for both proposed methods were compared successfully with those obtained from applying of UV method and measured the absorbance at $352 \mathrm{~nm}[30,31]$. The F and ttests [32] indicated that there are no considerable differences between batch, FI and UV methods for the assay of PIX in pharmaceutical dosage forms. Table 5 demonstrates the analytical characteristics for the proposed methods in addition to previously reported methods.

\section{CONCLUSION}

In conclusion, the batch and FI methods suggested for the analysis of PIX in commercial dosage forms have the characteristic features of being sensitive, inexpensive, using safely drug 
compound as a reagent and wide range of assay with no need for pre-extraction or heating, with good precision. High sampling frequency (38 sample/h) and the precision make FI procedure appropriate for the quality control of PIX in pharmaceutical formulations and faster than the batch methods. Experiments also indicated that there are no significant differences between the results obtained from the two proposed methods.

There are few FIA methods to determine PIX but many of which lack sensitivity, utilise toxic reagents or being highly costly. The proposed method in this study utilise cheap and safe reagents and provide a wide range of determination yet it presents high accuracy and precision.

\section{REFERENCES}

1. Vartanyan, R.S. Sintez osnovnykh lekarstvennykh sredstv (Synthesis of Main Pharmaceuticals), Meditsinskoe informatsionnoe agentstvo: Moscow; 2004.

2. Her Majesty Stationary Office, British Pharmacopoeia, Vol. I, Royal Pharmaceutical Society of Great Britain: London; 2002; 9939.

3. Spac, A.F.; Miftode, A.M.; Asaftei, I.V.; Sandu, I. Quality by design (QbD) approach to develop and validate a HPLC method for piroxicam from serum. Rev. Chim. 2018, 69, 21672171.

4. Dikran, S.B.; Mahmood, R.M. High performance liquid chromatographic method for the determination of piroxicam, naproxen, diclofenac sodium, and mefenamic acid in bulk drug and pharmaceutical preparations, J. University Babylon, Pure Appl. Sci. 2018, 26, 387-399.

5. Rezaei, M.; Rajabi, H.R.; Rafiee, Z. Selective and rapid extraction of piroxicam from water and plasma samples using magnetic imprinted polymeric nanosorbent: Synthesis, characterization and application. Colloids Surfaces A. 2020, 586, 124253.

6. Ghorbania, M.; Aghamohammadhasan, M.; Shams, A.; Tajfirooz, F.; Pourhassan , R.; Khosravi , S.R.B.; Karimi, E.; Jampour, A. Ultrasonic assisted magnetic dispersive solid phase microextraction for preconcentration of two nonsteroidal anti-inflammatory drugs in real water, biological and milk samples employing an experimental design. Microchem. $J$. 2019, 145, 1026-1035.

7. Otarola, J.; Lista, A.G.; Fernández Band, B.; Garrido, M. Capillary electrophoresis to determine entrapment efficiency of a nanostructured lipid carrier loaded with piroxicam. $J$. Pharma. Anal. 2015, 5, 70-73.

8. Dal, A.G.; Oktayer, Z.; Doğrukol-Ak, D. Validated method for the determination of piroxicam by capillary zone electrophoresis and its application to tablets, J. Anal. Methods Chem. 2014, 2014, 1-7.

9. Zhang, J.; Li, R.; Yao, L.; Wang, Z.; Lv, W.; Kong, F.; Wang, W. Highly sensitive determination of piroxicam using a glassy carbon electrode modified with silver nanoparticles dotted single walled carbon nanotubes-reduced graphene oxide nanocomposite. J. Electroanal. Chem. 2018, 823, 1-8.

10. El-Didamony, A.M.; Amin, A.S. Adaptation of a color reaction for spectrophotometric determination of diclofenac sodium and piroxicam in pure form and in pharmaceutical formulations. Anal. Lett. 2004, 37, 1151-1162.

11. Gowda, B.G.; Seetharamappa, J.; Melwanki, M.B., Indirect spectrophotometric determination of propranolol hydrochloride and piroxicam in pure and pharmaceutical formulations. Anal. Sci. 2002, 18, 671-674.

12. Al-Momani, I.F. Indirect flow-injection spectrophotometric determination of meloxicam, tenoxicam and piroxicam in pharmaceutical formulations. Anal. Sci. 2006, 22, 1611-1614.

13. El-Ries, M. A.; Mohamed, G.; Khalil, S.; El-Shall, M. Spectrophotometric and potentiometric determination of piroxicam and tenoxicam in pharmaceutical preparations. Chem. Pharm. Bull. 2003, 51, 6-10. 
Determination of piroxicam in pharmaceutical forms using flow injection-spectrophotometry 23

14. Sastry, C.S.P.; Prasad Tipirneni, A.S.R.; and Suryanarayana, M.V. Extractive spectrophotometric determination of some anti-inflammatory agents with methylene violet. Analyst 1989, 114, 513-515.

15. Sastry, C.S.P.; Rama Srinivas, K.; Krishna Prasad, K.M.M. Sevron blue 5G as an ionpairing reagent for the determination of acidic drugs in pharmaceutical formulations. Indian J. Pharm. Sci. 1996, 58, 120-122.

16. Amin, A.S. Spectrophotometric determination of piroxicam and tenoxicam in pharmaceutical formulations using alizarin. J. Pharm. Biomed. Anal. 2002, 29, 729-736.

17. Azmi, S.N.H.; Iqbal, B.; Jaboob, M.A.M.; Al Shaharia, W.A.S.; Rahman, N. Spectrophotometric determination of piroxicam via chelation with $\mathrm{Fe}$ (III) in commercial dosage forms. J. Chin. Chem. Soc. 2009, 56, 1083-1091.

18. Taha, E.A.; Salama, N.N.; Abdel Fattah L.E. Spectrofluorimetric and spectrophotometric stability-indicating methods for determination of some oxicams using 7-chloro-4-nitrobenz2-oxa-1,3-diazole (NBD-Cl). Chem. Pharm. Bull. 2006, 54, 653-658.

19. Kormosh, Z.A.; Hunka, I. P.; Bazel, Y. R. Spectrophotometric determination of piroxicam. J. Anal. Chem. 2011, 66, 378-383.

20. Tabrizi, A.B; Tutunchi, N.S. Analysis of piroxicam in pharmaceutical formulation and human urine by dispersive liquid-liquid microextraction combined with spectrophotometry. Adv. Pharm. Bull. 2013, 3, 37-44.

21. AL-Momani, I.F. Indirect flow-injection spectrophotometric determination of meloxicam, tenoxicam and piroxicam in pharmaceutical formulations. Anal. Sci. 2006, 22, 1611-1614.

22. Al-Kindy, S.M.Z.; Al-Wishahi, A.; Suliman, F.E.O. A sequential injection method for the determination of piroxicam in pharmaceutical formulations using europium sensitized fluorescence. Talanta 2004, 64, 1343-1350.

23. Sanchez-pedrefio, C.; Garcia, M.S.; Albero, M.I.; Rodriguez, J. Flow-injection spectrophotometric determination of piroxicam. J. Pharm. Biomed. Anal. 1993, 11, 933-938.

24. Yu, F.; Chen, F.; Zheng, S.; Chen, L.; Cui, M. Flow-injection chemiluminescent determination of piroxicam using tris(2,2'-bipyridyl)ruthenium(II)-potassium permanganate system. Anal. Lett. 2008, 41, 2412-2423.

25. Ruzicka J.; Hansen, E.H. Flow Injection Analysis, 2nd ed., Wiley: New York; 1988.

26. Al-Momani, I.F.; Rababah, M.H. Automated flow injection spectrophotometric determination of the proton pump inhibitor omeprazole in pharmaceutical formulations. Int. J. Pharm. Chem. 2017, 3, 52-55.

27. Al-Abachi, M.Q.; Hadi, H. Normal and reverse flow injection-spectrophotometric determination of thiamine hydrochloride in pharmaceutical preparations using diazotized metoclopramide. J. Pharm. Anal. 2012, 2, 350-355.

28. Al-Abachi, M.Q.; Abed, S.S. Spectrophotometric determination of Phenylephrine hydrochloride and Salbutamol sulphate drugs in pharmaceutical preparations using diazotized Metoclopramide hydrochloride. Baghdad Sci. J. 2015, 12, 167-177.

29. ICH Guideline Q2(R1), Validation of analytical procedures: text and methodology, November, 2005.

30. Singh, S.; Patel, J.R.; Kare, S. Estimation of piroxicam in tablet dosage form by using UVVis. Spectrophotometer. Asian J. Res. Chem. 2016, 9, 1-3.

31. Hadunann, E.R.M.; Gianoth, E.A.; Santoro, M.R.M. Determination of piroxicam in pharmaceutical preparations by ultraviolet difference spectophotometry and high performance liquid chromatography. Anal. Lett. 1993, 26, 259-269.

32. Miller, J.C., Miller, J.N. Statistics for Analytical Chemistry, Ellis Horwood: Chichester, UK; 1993. 